\title{
Missional ecclesiology as basis for a new church order: A case study
}

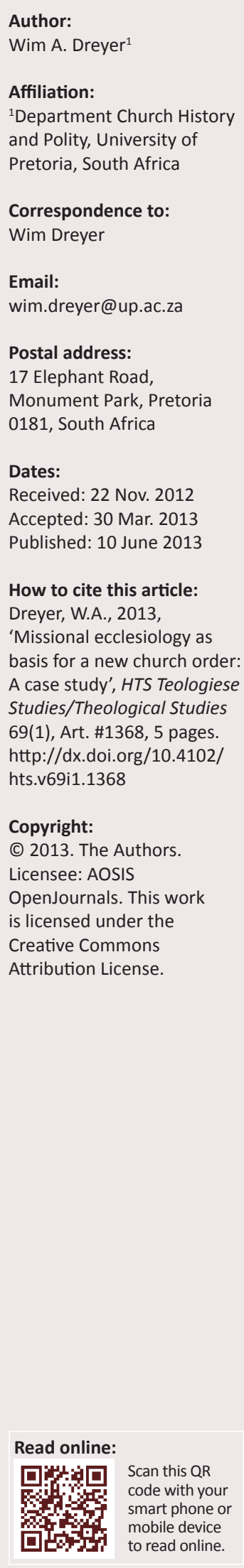

In this contribution the author looks at the ecclesiology and church polity of the Nederduitsch Hervormde Kerk van Afrika (NHKA) as a case study. Different approaches to ecclesiology and church polity by different NHKA theologians are examined. The conclusion is reached that a paradigm shift is required, to assist the church in the process of transformation. Part of the transformation process, is the creation of a church order with a stronger missional orientation. It is argued that, in the context of the 21st century, the missio Dei paradigm and missional ecclesiology could be a suitable point of departure in the creation of a new church order for the NHKA.

\section{Ecclesiological overview}

One of the important exponents of church polity in the Nederduitsch Hervormde Kerk van Afrika (NHKA) ${ }^{1}$ was A.D. Pont. Pont was professor of Church History and Church Polity from 1957 to 1992 at the University of Pretoria. He produced two volumes on church polity, Historiese Agtergronde van ons Kerklike Reg (Pont 1981, 1991). Included in these were the complete texts and discussions of the most important church orders of the Dutch and South African reformed churches.

Pont was of the opinion that the NHKA, as a church in the reformed tradition, could only be a church within the Calvinist and presbyterial-synodal ecclesiological paradigm (see Pont 1995:771-791). Due to his considerable influence over an extended period as professor of Church Polity, the presbyterial-synodal ecclesiology became structurally entrenched in the NHKA Church Order (NHKA 1997).

The writing and compilation of the 1997 Church Order started in 1983, a process in which Pont played an influential role. However, concurrently with this process, other opinions and criticisms were voiced.

One of the important critical voices was that of J.P. Oberholzer, professor of Old Testament Studies, Dean of the Faculty of Theology at the University of Pretoria (UP) and moderator of the General Assembly of the NHKA. In his opening address at a national convention of ministers in 1995, Oberholzer pleaded for a new approach in ecclesiology as well as church praxis.

His words reflected a growing impatience with an outdated ecclesiology. He pointed out that for several years there had been a pervasive sense that a more contemporary approach to ecclesiology was needed, which could lead to the transformation of the NHKA and a simplified approach to ministry (Oberholzer 1995:851). His criticism became even sharper when he wrote in 1999:

the new millennium confronts us with the failures of almost everything that kept the church occupied. The church is getting smaller; it struggles to survive economically; its theology became unusable and its political history lies shattered. (p. 449)

At more or less the same time, G.M.M. Pelser, professor of New Testament Studies (UP) started an extensive research programme on the different ecclesiologies to be found in the New Testament (Pelser 1995). His research clearly indicated the diversity of ecclesiologies distinguishable in the New Testament. His conclusion was that it is impossible to speak of 'the church' as if there is only one model of church present in the New Testament (Pelser 1995:647-673). In his research the following key concepts were developed:

- Being church implies discipleship.

- Being church implies a continuing laying-down of particularistic interests in favour of God's kingdom.

- The church is an eschatological community which will always remain pilgrims through history and will never have permanent dwelling in this world.

1.NHKA - One of the Afrikaans churches in South Africa in the Calvinistic reformed tradition. Known in English as the Netherdutch Reformed Church in Africa. 
- The unity with Christ and the indwelling of the Holy Spirit is fundamental to being a church.

- The church is a community of believers, who in Christ become friends, brothers, sisters, servants of God and disciples of Jesus willing and able to learn from him.

- To be a church means to be 'in Christ', to be one with him in his death and resurrection.

- Poverty and loss of family were real problems in the early Christian communities, which led to the understanding of the church as a caring community or the household of God'.

- The church lives as body of Christ under his governance. In such a way, the church became a reflection of the kingdom of God.

- The church is the sphere where the salvation in and through Christ is realised. This leads to reconciliation between God and his people, as well as reconciliation between people.

- The church is the temple of the Holy Spirit.

- In the later New Testament manuscripts (like the pastoral letters) the household of God includes members with certain gifts, which meant that they became leaders in the early communities. The eschatological second coming of Christ moved to the background. As a result, the building up and maintenance of the church became important. The focus shifted, from missional outreach to pastoral care. It is clear that even in the time of the New Testament writings, a gradual shift took place: the church evolved from a spiritual movement into a structure with certain rules, offices and traditions.

Another NHKA theologian, G.C. Velthuysen, propagated a move away from the prevalent ecclesiology of the NHKA. Velthuysen was professor of Systematic Theology at the University of Pretoria.

As early as 1988, Velthuysen proposed an 'experimental approach to ecclesiology' (1988:489). Following H. Ott and H-J. Kraus, Velthuysen built his ecclesiology on Christology. The church can be understood only in relation to Jesus Christ. An unbreakable and essential unity exists between Christ and his church.

Velthuysen also agrees with Karl Barth, who referred to the congregation as the earthly and historical existence of Christ (Barth 1953:738). This does not mean that Barth understood the church as Christus prolongatus, because in his typically dialectical approach he distinguishes sharply between Christ and the church. Christ and the church are one, but not in such a way that the church becomes deified. The identification of Christ and the church functions on another level, but still implies a radical identification of the church with Christ.

Velthuysen also refers to D. Bonhoeffer who spoke of the congregation as Christus existierend als Gemeinde (Velthuysen 1988:501). Thus the congregation is a priori a form of revelation. The church is Christ on earth. To be church, is to be one with Christ, to be in Christ. At the same time, he distinguishes between Christ as the head of the body and the church as his body.
Velthuysen comes to the conclusion that the church is not Christus prolongatus, but at the same time the church could never be without Christ (Velthuysen 1988:502). The unity between Christ and the church is a reality which could only be experienced through faith. In this manner, Velthuysen radically opposed an institutionalised form of church.

From another perspective, L.J.S. Steenkamp proposed a paradigm shift in our understanding of the church (1995:604-622). The paradigm of the Christendom is dead. A new paradigm needs to be developed which would be relevant to the 21 st century.

After a discussion of biblical metaphors such as the church as God's family; the church as a building of which Christ is the cornerstone; the church as God's people; the church as the body of Christ and others, he reiterates the necessity of conversion and a radical reformation of the church, as we approached the 21st century (Steenkamp 1995:619).

Steenkamp defined the new paradigm in terms of the missio Dei. The heart of being a church should be a missional and diaconal presence in the world which flows from a living faith in Jesus Christ (Steenkamp 1995:620).

\section{A new approach to ecclesiology}

Despite the critical voices, the Church Order was approved by the General Assembly of the NHKA in 1997. However, the feeling that a more contemporary and relevant ecclesiology and church order was needed remained. This is reflected in the publications of church leaders and theologians after 1997.

Since 2000, when J. Buitendag became professor of Systematic Theology at the University of Pretoria, ecclesiology received particular attention in his lectures and published work (Buitendag 2008). As moderator of the NHKA and also Dean of the Faculty of Theology, he was influential in bringing about a new understanding of the church. His ecclesiology reflects influences from theologians such as Berkhof, Dingemans, Küng, Moltmann, Pannenberg and Zizioulas. He also accentuated an ecumenical approach to ecclesiology, more specifically the work done by Faith and Order (Faith and Order 1998, 2005). His ecumenical understanding of the church became even more visible in his efforts to restore the NHKA's membership of the then World Alliance of Reformed Churches (WARC).

Under his leadership the moderature of the NHKA hosted a National Colloquium from 27 to 29 April 2006. The theme of the colloquium was 'Identity and relevance of the NHKA in the 21st century'.

In his opening address at the National Colloquium (Buitendag 2006), Buitendag confronted the NHKA with a clear and unequivocal challenge: The church must enter a process of transformation, or it will become totally irrelevant in the 21st century. One of the authors he referred to was Pete Ward, with his concept of a 'liquid church' (Ward 2002). Buitendag (2006:8) envisaged a church which could become 
more adaptable, like water that flows in a clear and lifegiving stream. The church needs to become a dynamic, communicative network, distinguished by its participatory nature under the direction of the Holy Spirit and the Word. The church can only exist in a living relationship with Jesus Christ, as part of the one body of Christ.

Another influential figure in the NHKA is T.F.J. Dreyer. Dreyer served several terms as moderator of the NHKA. Under his leadership, during 2001, the NHKA adopted a vision: 'Our dream is that all people will believe in Jesus Christ as the only hope for the world.' This speaks of more open, missional and inclusive ecclesiology.

As the first decade of the 21st century passed, Dreyer (2009:427-431) became more outspoken in his criticism of a traditional approach to ecclesiology. As professor of Practical Theology, he developed a practical ecclesiology very much influenced by the thoughts of Gerben Heitink (Heitink 2007). He uses Heitink's ecclesiological matrix, indicating the high level of stagnation in the NHKA and its inability to adapt to a new context. He came, as Heitink, to the conclusion that the church should enter a process of 'radical reformation'.

The question is: How does a 'radical reformation' take place? What are the fundamental issues at stake? In general terms, it is accepted that change only takes place once we change our understanding of reality, when we create a new language and work creatively with new ideas and new realities. From this, one may deduce that 'reformation' should start with a new understanding of the nature of the church. In the NHKA, as mentioned above, this process of theologically reimaging the church already started several decades ago, running parallel to the more traditional reformed understanding of the church. With the ecclesiological paradigm shift as well as the realisation that a more missional approach to ministry and church order is necessary, the 68th General Assembly (2007) started a process of rewriting the Church Order - only ten years after it had been approved.

\section{Biblical metaphors}

As part of this process, a committee was appointed to work on an ecclesiology which could form the basis of a new church order. The complete text of the report is to be found in the agenda of the 69th General Assembly (NHKA 2010:522-534), under the heading 'Ekklesiologiese kontoere met die oog op die herskryf van die kerkorde.' When the text of the report on ecclesiology is examined the principles on which it is based, become clear:

- The report is based on a missional ecclesiology.

- The report uses biblical metaphors in its ecclesiological exposition. The biblical metaphors were structured in accordance with the Trinity: the one God who revealed himself as Father, as the Son and the Holy Spirit.

- The basic principle reflected in this approach is the conviction that our understanding of God is fundamental to our understanding of the church. The way we speak about the church reflects our understanding of God.
The biblical metaphors were placed under the following headings:

- The congregation as God's people:

- We are God's people

- We are part of the covenant

- We are God's people in this world

- We are God's people on a pilgrim's journey

- The congregation as the family of the Father:

- We are the household of the Father

- We are a family

- We care for each other

- We eat at the same table

- The congregation as the body of Christ:

- We are the body of Christ

- We are one in Christ

- We are called and equipped for service

- We are baptised into the body of Christ

- The congregation as the temple of the Holy Spirit:

- We are the temple of the Holy Spirit

- We received the Holy Spirit

- We are guided and equipped by the Holy Spirit

- We worship God under guidance of the Holy Spirit

Pieter Coertzen, as the leading exponent of church polity in South Africa, refers to these metaphors, but with hesitation (Coertzen 1991:80). He agrees that the different biblical metaphors are important for our understanding of the church and church polity, but that it would be impossible to investigate all the metaphors and their relevance to a church order. He then continues to discuss the term ekklesia and its relevance to church polity.

The question still remains: Should we, and could we, translate the different biblical metaphors pertaining to the church into a workable and practical church order?

I believe that in view of the challenges facing the church, these metaphors could give some answers to very difficult questions. We need to translate a biblical ecclesiology into a functional church order and relevant congregational ministry, considering the complicated nature of metaphors. A metaphor calls to mind a whole world of meaning. Some of the nuances are lost over time. New meanings are attached to metaphors. Every generation and culture attach new meaning to a metaphor. This should be taken into account when utilising biblical metaphors.

\section{Missional ecclesiology}

In my view, the NHKA needs to move from a typical presbyterial-synodal ecclesiological paradigm to a missio Dei paradigm, based on missional ecclesiology. But what is missional ecclesiology? Many definitions have been suggested and worked out in considerable detail, for instance, Hirsch (2006) and Niemandt (2007). A workable and short definition of missional ecclesiology (from a reformed perspective) was given by Hooker (2008):

Missional ecclesiology demands more of the church than deciding which community service projects to undertake or setting congregational priorities for the coming year. Missional 
ecclesiology is a way of understanding the church. It begins with the Missio Dei - God's own 'self-sending' in Christ by the Spirit to redeem and transform creation. In a missional ecclesiology, the Church is not a building or an institution but a community of witness, called into being and equipped by God, and sent into the world to testify to and participate in Christ's work. The Church does not have missions; instead, the mission of God creates the Church. The Church serves God's call to mission through its work in three broadly defined categories: the proclamation of the Word of God, the administration of the sacraments of Baptism and the Lord's Supper, and the nurture of the covenant community of disciples. It undertakes this mission without regard for its own agenda or survival. (pp. 1-2)

Central to missional ecclesiology is the theological concept of the missio Dei. The essence of being church is to be found in its participation in God's mission to the world. As such, the missio Dei is the basis and point of departure for congregational ministry (Bosch 1991:467ff.).

Another aspect that needs to be considered is the increased focus on the local congregation. All over the world, a process of 'congregationalisation' is evident (Chandler 2001:210; Volf 1998:13). This is also happening in the NHKA. More and more, congregations refuse to abide by the decisions taken by the synod or the moderature.

Missional ecclesiology emphasises the continuing conversion of the church (Guder 2000:150) and congregational praxis. Fundamental to transformation is a shift in focus, from congregational maintenance to openness to the world and participation in God's mission and God's kingdom.

Question would be: How this trend could be accommodated and linked up with a missional ecclesiology and what would be the effect on the identity of the NHKA? How would greater autonomy of the local congregation affect the unity of the NHKA as one, national church? Does a missional ecclesiology, as defined by Hirsch $(2006: 17,64)$ and others as fundamentally anti-institutional, really lend itself as ecclesiological basis for a church order?

\section{Ecclesiology - church order - ministry}

There is a direct interdependence of ecclesiology, church polity and ministry. Church polity and church order is based on ecclesiology, on our understanding of what the church is and should be (Koffeman 2009:16-21). The way we understand the church, defines our church polity which in turn influences the congregational praxis and ministry. Even more, the way we understand God reflects in the way we understand the church and its calling in this world.

Based on the presbyterial-synodal ecclesiology and church order, ministry in the NHKA could be described as fundamentally pastoral. The 1997 Church Order creates de iure a situation where $90 \%$ of congregational activities are centred on pastoral ministry (NHKA 1997, Ord. 2.1.5, 2.3 \& 2.4). This reflects the normal reformed type of ministry which centres on the activities of the minister, elder and deacon. Characteristics of a pastoral ministry are the following:
- Pastoral ministry has a strong focus on church members attending the Sunday service. A 'good' church member is one who regularly attends the Sunday service. Over centuries Sunday service became the undisputed focal point of ministry. The world must come to church on Sunday - but does the church go to the world on weekdays? Ministry is the responsibility of the minister, elder and deacon.

- Ordinary church members have a very limited role in congregational ministry. There is a clear distinction between the responsibilities of ordinary church members and those holding office in the church, although Luther and Calvin emphasised the importance of the priesthood of all believers. However, with time, the overemphasis on the offices and continued institutionalisation of the church minimalised the role of church members.

- Pastoral ministry is to a large extent dependant on the efficacy of the pastor loci.

- Pastoral ministry is focused inward, giving high priority to pastoral care and the maintenance of congregational structures.

- Pastoral ministry has an inherent weakness in terms of missional ministry. Missional ministry, as research has shown, receives very little attention in traditional reformed congregations with a strong focus on pastoral care (Dreyer 2011:109-115).

The 68th General Assembly of the NHKA (2007:36-38) came to the conclusion that missional ministry should be emphasised. Ministers were encouraged to facilitate a shift from pastoral ministry to missional ministry, without compromising pastoral care in congregations:

1. The General Assembly confirms that missional ministry is an important part of congregational ministry and enough time should be devoted to it.

2. The General Assembly encourages congregations to start with a process of transformation and development, of which missional ministry should be the primary focus.

The debate on missional ministry was continued during the 69th General Assembly (2010). During this debate terminology was clarified and a distinction was made between missionêr and missionaal:

- The first identifies mission as an external activity with a strong focus on missionary work done elsewhere and in the format of support to specific projects or missionary endeavours.

- The second indicates a missional mode of existence and paradigm, where a missional approach is part of the daily functioning of a congregation. The DNA of the congregation should become missional, which determines the way in which a congregation (as the people of God, the family of the Father, the body of Christ and the temple of the Holy Spirit) is present in the world. (NHKA 2010:235)

The General Assembly clearly stated that missional ministry has as its point of departure, the great commission of Jesus Christ (Mt 28) and came to the conclusion that missional ministry should form an essential part of reformed ministry. 


\section{Concluding remarks}

\section{A new church order}

The reformation of the church which is needed in the 21st century, leaves nothing untouched and requires changes at the deepest levels of the church (Niemandt 2007:52). Adaptive change begins with a new understanding of what it means to be a church. Adaptive change is about changing the hearts and minds of individual congregants as well as the church collectively.

In this regard, we must consider what Alan Hirsch (2006) wrote:

Restructure the organization and leave the systems story in place, and nothing changes in the organization. It's futile trying to revitalize the church, or a denomination, without changing the system. (p. 54)

Hirsch (2006:53) defines a systems story as the set of core beliefs which results from the multiplicity of conversations and that maintain the unity of culture. This becomes evident in the following:

- the way in which theology is taught and functions in the church

- myths

- symbols

- structures embedded in official authority

- organisational structures

- systems of control

- rituals.

Applying Hirsch's analyses and definitions to the NHKA as our case study, it is my contention that the dominant system story of recent decades could be described in terms of the generally accepted presbyterial-synodal ecclesiology and church order, resulting in an inwardly focused pastoral ministry and liturgy.

I believe NHKA should engage in a process of transformation (as an internal process) as well as reformation (as a structural process). This will only be possible if the dominant system story migrates to a missional understanding of the church and of ministry, without compromising the quality of pastoral care. This is an extraordinary complex process that needs to be facilitated with extreme care, part of which will be the writing of a new church order. How a missional ecclesiology will impact on issues such as discipline, the functioning of offices and the general priesthood of all believers - to name just a few - will need to be worked out.

Writing a new church order is therefore not a question of superficial and cosmetic changes, but rather based on a deep and fundamental transformation of our understanding of the church, its mission and the way ministry should be structured.

\section{Acknowledgements Competing interests}

The author declared that he has no financial or personal relationships that may have inappropriately influenced him in writing this article.

\section{References}

Barth, K., 1953, Kirchliche Dogmatik IV/1, EVZ-Verlag, Zürich.

Bosch, D.J., 1991, Transforming mission, Orbis Books, New York.

Buitendag, J., 2006, Openingsrede, Nasionale Colloquium 27 April 2006, Nederduitsch Hervormde Kerk van Afrika, Kerkargief, Pretoria.

Buitendag, J., 2008, 'Ecclesia reformata semper reformanda - die ongemaklike eis', HTS Teologiese Studies/Theological Studies 64(1), 122-138. http://dx.doi.org/10.4102/ hts.v64i1.7

Chandler, R., 2001, Racing towards 2001: The forces shaping America's religious future, Zondervan, Grand Rapids.

Coertzen, P., 1991, Gepas en Ordelik: 'n Teologiese verantwoording van die orde van en in die kerk, RGN, Pretoria.

Dreyer, T.F.J., 2009, "n Kerk met karakter: Die perspektief van Gerben Heitink', HTS Teologiese Studies/Theological Studies 65(1), 427-431. http://dx.doi.org/10.4102/ hts.v65i1.315

Dreyer, W.A., 2011, 'Praktiese ekklesiologie en bedieningspraktyk met verwysing na die Nederduitsch Hervormde Kerk van Afrika', PhD proefskrif, Departement Praktiese Teologie, Universiteit van Pretoria.

Faith \& Order, 1998, The nature and purpose of the church, World Council of Churches, Geneva.

Faith \& Order, 2005, The nature and mission of the church, World Council of Churches, Geneva.

Guder, D.L., 2000, The continuing conversion of the church, Wm. B. Eerdmans Publishing, Grand Rapids. (The Gospel and our culture series). PMCid:110582

Heitink, G., 2007, Een kerk met karakter - Tijd voor heroriëntatie, Uitgeverij Kok, Kampen. PMid:17973879

Hirsch, A., 2006, The forgotten ways: Reactivating the missional church, Brazos, Grand Rapids.

Hooker, P., 2008, 'What is missional ecclesiology', in Northeast Georgia Presbytery, viewed 20 March 2010, from http://www.negapby.org/missionalecc.pdf

Koffeman, L.J., 2009, Het goed recht van de kerk: Een theologische inleiding op het kerkrecht, Uitgeverij Kok, Kampen. PMid:19877047

Nederduitsch Hervormde Kerk van Afrika (NHKA), 1997, Kerkorde van die Nederduitsch Hervormde Kerk van Afrika, Nederduitsch Hervormde Kerk van Afrika Kerkargief, Pretoria.

Nederduitsch Hervormde Kerk van Afrika (NHKA), 2007, Besluitebundel van die 68e Algemene Kerkvergaderingbundel, Nederduitsch Hervormde Kerk van Afrika Kerkargief, Pretoria.

Nederduitsch Hervormde Kerk van Afrika (NHKA), 2010, Agenda van die 69e Algemene Kerkvergadering, Nederduitsch Hervormde Kerk van Afrika Kerkargief, Pretoria.

Niemandt, N., 2007, Nuwe drome in nuwe werklikhede: Geloofsgemeenskappe in pas met' $n$ postmoderne wêreld, Lux Verbi BM, Wellington.

Oberholzer, J.P., 1995, 'Die kerk', HTS Teologiese Studies/Theological Studies 51(3), 851-857. http://dx.doi.org/10.4102/hts.v51i3.1441

Oberholzer, J.P.,1999, 'Terug op die pad', in D.J.C. van Wyk (red.), 20ste Eeu Hervormde Teologie, bl. 449-462, SENTIK, Pretoria.

Pelser, G.M.M., 1995, 'Die kerk in die Nuwe Testament', HTS Teologiese Studies/ Theological Studies 51(3), 645-676. http://dx.doi.org/10.4102/hts.v51i3.1421

Pont, A.D., 1981, Historiese agtergronde van ons kerklike reg, deel 1, HAUM, Pretoria. PMCid:1537413

Pont, A.D., 1991, Historiese agtergronde van ons kerklike reg, deel 2, Kital, Pretoria. PMCid:1130626

Pont, A.D., 1995, 'Die reformatoriese kerkbegrip: Enkele groot lyne op grond van Calvyn se uiteensetting', HTS Teologiese Studies/Theological Studies 51(3), 771-791. http:// dx.doi.org/10.4102/hts.v51i3.1434

Steenkamp, L.J.S., 1995, 'Die kerk onderweg na die 21e eeu: 'n Kritiese besinning oor kerkwees in ' $n$ veranderende konteks in Suid-Afrika', HTS Teologiese Studies/ Theological Studies 51(3), 604-622. http://dx.doi.org/10.4102/hts.v51i3.1418

Velthuysen, G.C., 1988, 'Die wese van die kerk: 'n Teologiese antwoord op 'n filosofiese vraag', HTS Teologiese Studies/Theological Studies 44(2), 489-513.

Volf, M., 1998, After Our Likeness: The Church as an image of the Trinity, Wm. B. Eerdmans Publishing, Grand Rapids.

Ward, P., 2002, Liquid Church, Paternoster Press, Carlisle. 